\title{
ファジィ推論を用いたガス判別法の提案
}

\author{
青 木 徹* 小 西 亮 介*・木 村 壽 成* ・末 次 大 祐*
}

\section{The Proposal of Gas Discrimination by Using Fuzzy Reasoning}

Tohru AokI*, Ryousuke Konishi*, Hisanari KImuRA* and Daisuke SueTsugu*

We tried gas discrimination by using one semiconductive gas sensor.

As a method of gas discrimination, we used the fuzzy reasoning with fuzzy set of slope of gas pattern which is divided into arbitatry interval.

As a result, we got a good successful rate for hydrogen $66.6 \%$, propane $79.1 \%$, butane $100 \%$, methan $100 \%$, city gas $79.1 \%$, and alcohol $91.6 \%$.

Key Words : gas discrimination, gas sensor, fuzzy reasoning

\section{1.はじめに}

最近の研究動向はセンサ回路やその用法によるガス選 択性の向上が試みられており特にセンサのインテリジェ ント化が進んでいる。

われわれもこうしたセンサの知能化の動向に着目し， 今まで，接触燃焼式ガスセンサ(セイコー社製)を用い ファジィ推論によりガスの判別を行ってきた1).ファ ジィ理論の応用でのガス判別では石㴊らのファジィ線形 予測法を用いた例もある2). 以前われわれが用いたセン サ（接触燃焼式）は濃度に対して出力は比例するが感度が 低くブリッジ回路を用いて増幅する必要があった。一方, 半導体センサは，接触燃焼式に比べて感度が高くブリッ ジ回路の必要がないため回路構成が簡略化できる.しか し半導体センサは濃度に対して出力が比例しないなど, 以前の方法では使用できない。 そこでセンサの複合化を 行ううえでの基礎実験として一つのセンサでのガス選択 性をもつ方法を考案した。 センサ一つで判別を試みたの は，ガス固有の情報を一つのセンサから最大限まで引き 出すことにより，今後複数化するうえでの基礎とするた めである.今回は半導体ガスセンサ（フィガロ社製, TGS-813） 1 個で， 6 種類の可燃性ガス，水素，ブタン， プロパン, メタン, 都市ガス, アルコールについての判

\footnotetext{
* 鳥取大学工学部 鳥取市湖山町南 4-101

* Faculty of Engineering, Tottori University, Tottori (Received January 27, 1992)

(Revised May 27, 1992)
}

別を試みた。

\section{2. 温度特性の測定}

Fig. 1 に示すような測定装置を用いてガスの特性を測 定した. ガス導入チャンバーは $2.4 l$ で，ガスはチャン バーの上部から注射器で導入した。 センサの電圧変化を センサに直列につないだ $10 \mathrm{~K} \Omega$ の抵抗の電压としてデ ジタルマルチメータで読み取り，それをPC-9801に送 り，取り込みデータの処理を行った。

ガス判別の前準備としてセンサの特性の測定では, 通 常センサの定格ヒ一夕電圧 $(5 \mathrm{~V})$ で使用される。その場 合異なったガスを導入しても, センサ感度にそれほどの 違いがみられない。しかしガスに対するセンサの温度特 性はガス種によって異なっている，そこでセンサに対す るヒータの電圧を途中でコンピュータにより自動制御

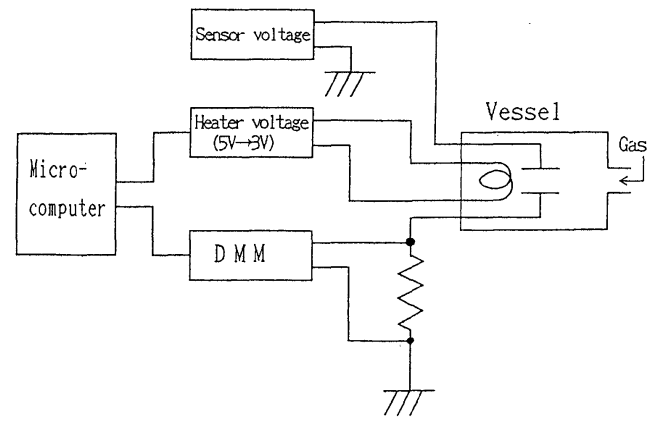

Fig. 1 Block diagram of measurement system 
で, $3 \mathrm{~V}$ に切り替えてヒータの温度を変化させ,このとき のガスによる応答特性の違いを判別に利用することを試 みた。

測定された, 各ガスの濃度 $1000 \mathrm{ppm}$. のときの温度変 化による特性を Fig. 2 に示す.電圧の切り替えはガスの 導入後, $5 \mathrm{~V}$ の電圧が安定した 40 秒後に行い, そして 3 $\mathrm{V}$ に切り替えた後の変化をみたものである。この結果, 各ガスによりその特性変化が異なっており，ガスの判別 に利用できることがわかった。

たとえば, プロパンガス, ブタンガスの感度は, 一度 下降したあと上昇しまた再び下降する特徴をもってい る。また，メタンガスは切り替え後は感度が下がり続け る.

都市ガス, 水素ガス，アルコールの場合は，切り替え た後は一度下がったあとは上昇を続ける。しかし，ガス の応答の形状と感度電圧が似通っており, センサの感度 電圧だけでは，これらのガスを判別することは困難であ る。またセンサは使用環境に左右されやすく感度にもば らつきを生じてしまう. そのためこのばらつきを配慮し たうえで, 判別要素となるものを考える必要があった。 またその要素はできるだけ単純であれば今後複数化する 上で非常に楽になるという考えをもとに判別法を作成し た.

\section{3. 判別要素の決定}

これらのガスの特性をみて人間が思うことはガスに応 じて,「感度が大きく変化した後, 少し上昇して, 今度は 少し減少する」とか「傾きがちょっと下がった」, などが スのパターンを具体的な数值ではなく，ばらつきを含ん でいても感覚で理解する、これをうまくコンピュータで 処理するためにファジィ推論を用いれば良いのではない かと考えられる。

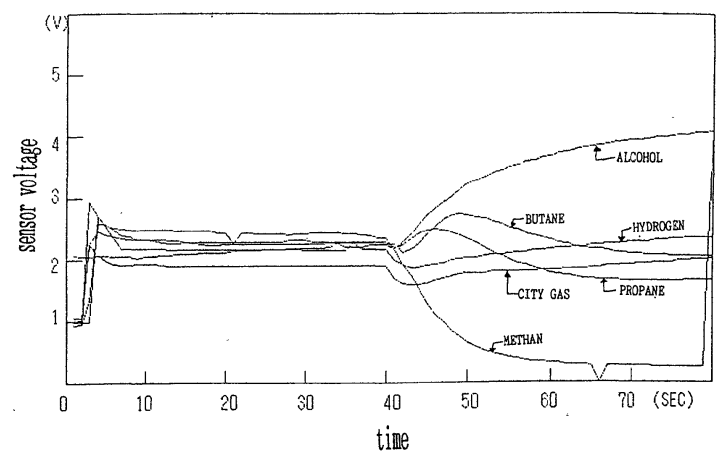

Fig. 2 The characteristics of output voltage of a sensor for six gases at $1000 \mathrm{ppm}$ after the change of heater voltage from $5 \mathrm{~V}$ to $3 \mathrm{~V}$
そこで測定した特性から，つぎのような方法を考えた。 これらのガスパターンを任意の時間で何点かに区切る. それは適当で良く厳密に何秒後でなくてはならないとい うわけではない. 人間がみて「だいたいこの辺でパター ンに変化があるな」と思う点を示してやればよい.この ようにして区切った回数が推論回数となる．たとえばガ スのパターンを

1）「最初は少し下がって」

2）「つぎにやや上がって」

3）「最後に少し上がる」

と推論回数 3 回で区切ることになる.

$n$ 回区切った時間を $t_{1}, t_{2} \cdots t_{n}$ とすれば，その $t_{1}, t_{2}$ の 間の変化分をまず角度に置き換え，その值をメンバー シップ関数に当てはめる，角度に変えたのは人間がみて そのほうがわかりやすいと考えたためである。

まず，測定されたガスのパターンをファイルに記憶し ておく.これを利用して Fig. 3(a) に示すような方法で, その選んだパターンについて，決定された時間ごとに角 度を計算する.その角度についてメンバーシップ関数に より傾きのグレードを求める。求めたグレードを，その ガスと傾きの関係として行列化する，それを全てのガス 種, 全ての推論時間区分に対して行う.

この推論に使用したメンバーシップ関数を Fig. 3(b)に 示す.これは, 1 秒間に士0.04 V 変化した場合を \pm 90 度 とし，それから \pm 30 度おきに区切った. $\pm 0.04 \mathrm{~V}$ という 值は経験的に得られた值で, センサの 1 秒当りの変化分 の最大值である(この值はセンサによって違いがある).

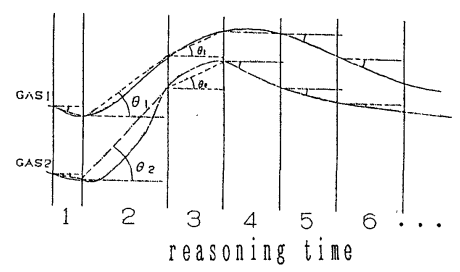

(a) The transformation to angular value of sensor voltage

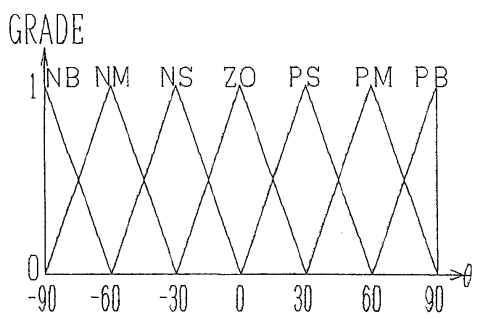

(b) Membership functions between $-90^{\circ} \sim+90^{\circ}$ for fuzzy reasoning system

Fig. 3 


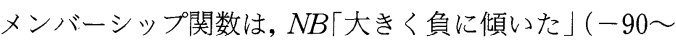
-60)，NM「やや負に傾いた」(-90〜ー30), NS「少し 負に傾いた」(－60～0)，ZO「傾いてない（変化ない）」 $(-30 \sim+30), P S\lceil$ 少し正に傾いた」 $(0 \sim+60), P M\lceil や$ や正に傾いた」(30〜90)，PB「大きく正に傾いた」 （60〜90）とした三角形のものを用いた.

これにより以下のような行列を推論回数分作成する. この行列はガスの特徵をファジィ化したものになり，ガ ス種を $n$ 種とすれば,

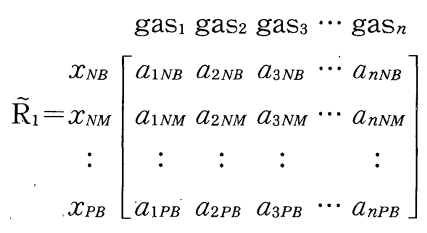

とおける. 行列要素 $a$ の添え字の数字はガス種の番号 を, $N B, N M, P B$ はメンバーシップ関数につけられた ラベルを示している.

この $\tilde{\mathrm{R}}$ は入力

$$
\tilde{\mathrm{A}}_{1}=\left[x_{N B}, x_{N M}, x_{N S}, x_{Z 0}, x_{P S}, x_{P M}, x_{P B}\right]
$$
に対して

$$
\widetilde{\mathrm{B}}_{1}=\left[\operatorname{gas}_{1}, \operatorname{gas}_{2}, \cdots, \operatorname{gas}_{n}\right]
$$

を出力するシステムになる.ここで $\tilde{\mathrm{A}}$ はガスの傾き $N B$ から $P B$ までの入力グレード, $\widetilde{\mathrm{B}}$ は各ガスの出力グレー ドとなる、 $\tilde{\mathrm{A}}, \tilde{\mathrm{B}}, \widetilde{\mathrm{R}}$ の添え字は推論回数を, $x$ の添え字は メンバーシップ関数のラベルを, そして gas の添え字は ガス種の番号を示す。

実験では,ガス導入後センサの電圧をほぼ安定させた, 40 秒が経過したのちに, センサ電圧を $5 \mathrm{~V}$ から $3 \mathrm{~V}$ に自 動制御で切り替える. そして決定した時間ごとにセンサ 電圧の変化分の角度を計算させる。

計算した值をメンバーシップ関数に当てはめ, NB か らPB までのグレードを計算し, 入力, $\tilde{\mathrm{A}}$ とあらかじめ作 成したファジィ行列 $\widetilde{R}$ との合成を行う. それにより出力

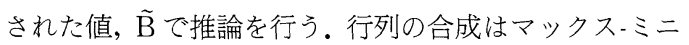
マム合成を用いた。われわれの実際の推論式は以下のよ

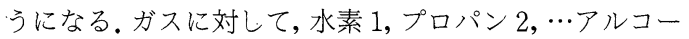
ル 6 と番号をつける. いま推論回数 1 回目に挍いて, 各 ガスの出力グレードは

$\widetilde{\mathrm{B}}_{1}=\left[\right.$ hydrogen $_{1}$, propane $_{1}$, butane $_{1}$, methan $_{1}$, city gas $_{1}$, alcohol $\left._{1}\right]$

となる.ガス名につけられた添え字は推論回数を示して いる.それぞれの值は

$$
\tilde{\mathrm{B}}_{1}=\tilde{\mathrm{A}}_{1} \circ \tilde{\mathrm{R}}_{1}
$$

により求められる.

䓰のそれぞれは

$$
\begin{aligned}
\text { hydrogen }_{1}= & \left(x_{N B} \cap a_{1 N B}\right) \cup\left(x_{N M} \cap a_{1 N M}\right) \\
& \cup \cdots \cup\left(x_{P B} \cap a_{1 P B}\right) \\
\text { propane }_{1}= & \left(x_{N B} \cap a_{2 N B}\right) \cup\left(x_{N M} \cap a_{2 N M}\right) \\
& \cup \cdots \cup\left(x_{P B} \cap a_{2 P B}\right) \\
\text { alcohol }_{1}= & \left(x_{N B 1} \cap a_{6 N B}\right) \cup\left(x_{N M} \cap a_{6 N M}\right) \\
& \cup \cdots \cup\left(x_{P B} \cap a_{6 P B}\right)
\end{aligned}
$$

と計算される. $a$ の添え字はガス種の番号を示している.

そして 1 回目の推論が終われば, 推論結果 $\widetilde{B}_{1}$ とつぎ の推論結果 $\widetilde{\mathrm{B}}_{2}$ をとめ, それぞれのガス別のミニマム をとり，ガスのグレードを決定する．たとえば水素なら

hydrogen $=$ hydrogen $_{1} \cap$ hydrogen $_{2}$

これを行列要素ごとに行い,

$$
\mathrm{GAS}=\left(\widetilde{\mathrm{B}}_{1} \cap \widetilde{\mathrm{B}}_{2}\right)
$$

となる.ここで GAS は，ガスのファアジィ集合である.

そのとき，各ガスのグレードがある值より小さくなれ ばそのガスではないとして推論の対象から除外しそのガ スのグレードを０とする（今回は除外のガスグレードを 0.01 以下として計算を行った.この值は推論を正しく行 ううえで，影響をほとんど与えていないと思われる。 こ の值を大きくすれば単純に推論回数は減少するが誤判別 割合も多〈なるであろう).

これを繰り返し，もしも設定した推論回数よりも前に ガス種を一つに決定できればそこで推論を終了する。

最終的に何種類かのガスが残つた場合，その中でグ レードのマックスをとり，ガス種を決定する．推論回数 を $n$ とすれば,

$$
\mathrm{GAS}=\cup\left(\widetilde{\mathrm{B}}_{1} \cap \widetilde{\mathrm{B}}_{2} \cap \cdots \widetilde{\mathrm{B}}_{n}\right)
$$
となる。

このような方法で, 各为スについて判別実験を行った。 推論回数は 8 回とした.

\section{4. 実験および結果検討}

コンピュータに測定電圧を取り込み計算させ, その後, 判別プログラムによりどのガスかを決定した。

6 種のガスの判別率と平均推論回数を Table 1 に示 す. 各ガスについて 24 回ずつ実験した結果である。これ をみる限りではほぼ良い結果ではあるが，判別率から文 ると水素ガスについては $66 \%$ ときわて判別率の低い 值となった，誤判別ガスは都市ガスとアルコールで，誤 判別について検討するために推論の際のグレードの変化 を示す。

Fig.4(a ) はメタン，（b ）はプロパン，（c）はブタン, (d) は水素, (e ) は都市ガス, ( f ) はアルコールの推論 の際のグレード変化を示している。これは各ガスについ て推論 24 回の平均である.平均すればどのガスについて も目的とするガスのグレードが一番大きくなっており, 
青木・小西・木村・末次：ファジィ推論を用いたガス判別法の提案

Table 1 Results of gas discrimination

\begin{tabular}{l|c|c|c|c|l}
\hline \hline Gas name & $\begin{array}{c}\text { Number } \\
\text { of data }\end{array}$ & $\begin{array}{c}\text { Number } \\
\text { of fault }\end{array}$ & $\begin{array}{l}\text { Successful } \\
\text { rate(\%) }\end{array}$ & $\begin{array}{l}\text { Reasoning } \\
\text { time(Av.) }\end{array}$ & $\begin{array}{l}\text { Gas name of an error } \\
\text { in discrimination }\end{array}$ \\
\hline \hline hydrogen & 24 & 8 & 66.6 & 8 & Alcohol, City gas \\
\hline propane & 24 & 5 & 79.1 & 3.04 & Butane \\
\hline butane & 24 & 0 & 100 & 4.78 & \\
\hline methane & 24 & 0 & 100 & 2 & \\
\hline city gas & 24 & 5 & 79.1 & 8 & Hydrogen, Alcohol \\
\hline alcohol & 24 & 2 & 91.6 & 5.5 & Hydrogen, City gas \\
\hline
\end{tabular}

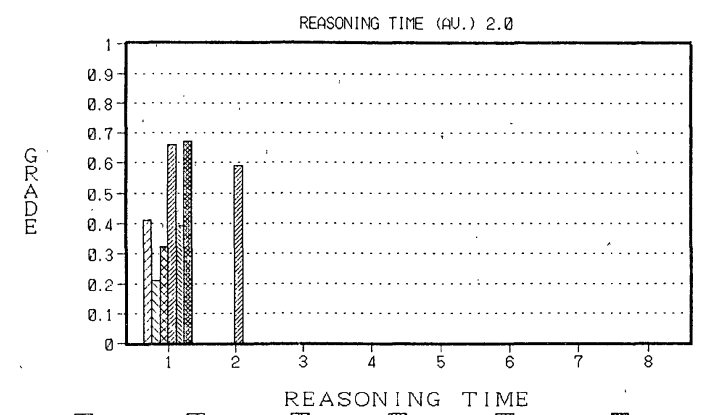

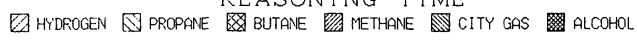

(a) Methane

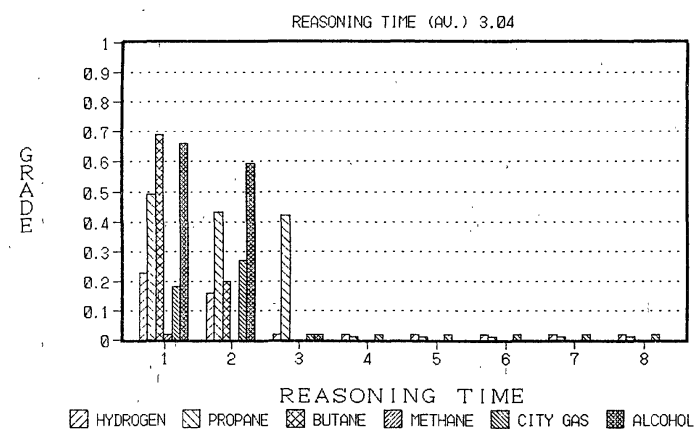

(b) Propane

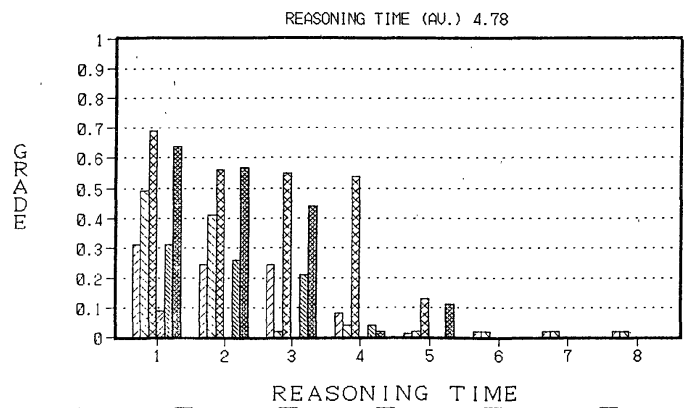

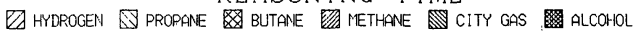

(c) Butane

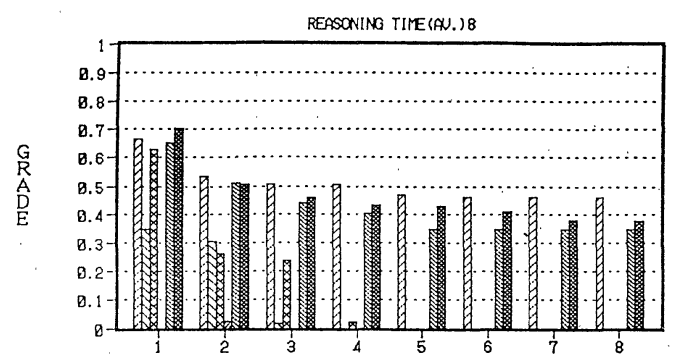

REASONING TIME

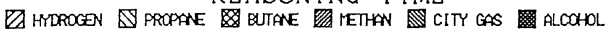

(d) Hydrogen

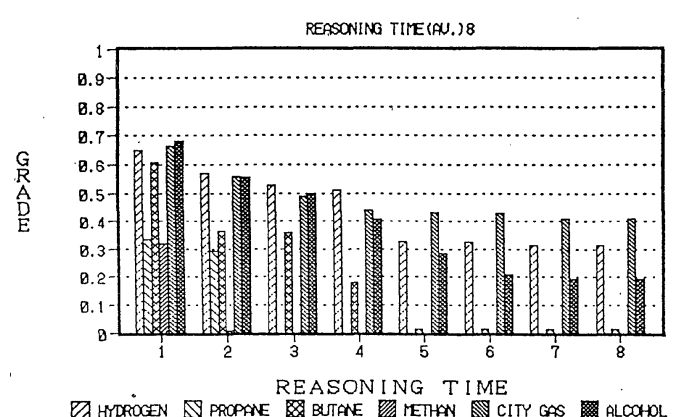

(e) City gas

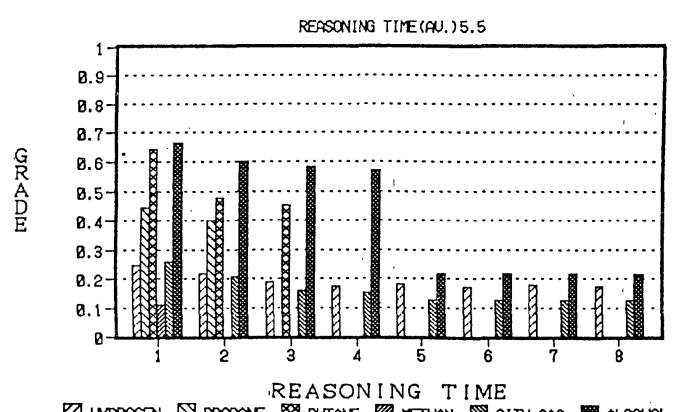

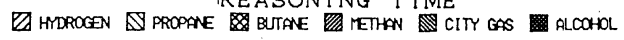

(f) Alcohol

Fig. 4 The gas grade of each reasoning time on the average of 24 times measurement 
推論方法に問題はないと思われる，水素，都市ガスは平 均推論回数 8 回である.ここで推論回数 5 回目以降はほ とんどグレードに変化がない. この結果は, 推論回数を 細かくしても特徵のない部分は推論の対象とならないこ とをしめしている.今後はこの点に留意する必要がある. 各ガス別にみると以下のような結果である.

メタン；最少推論回数 2 回で判別を行ったのはメタン ガスで,これはほかのガスに比べて特徵的であり, $5 \mathrm{~V}$ か ら $3 \mathrm{~V}$ に切り替えた後一定して感度が減少する.このた め推論 2 回目ですでにほかのガスと異なっており判別は 容易であった.

プロパン；プロパンの特徴は感度上昇後の減少の時間 がブタンガスより若干速く, その部分が推論 3 回目に当 たる時間である、その特徴をとらえて判別したと思われ る.

ブタン；ブタンガスはそのパターンの形状はプロパン と似ている. センサ感度の変化では上昇後, 減少する. 減少する時間はプロパンより遅いが, 水素, 都市ガス, アルコールはその時間では減少をすることはない. その ためほぼ推論 4 回目に当たる時間でガス判別を行ったと 思われる。

アルコール ; アルコールの場合, 高濃度では, 決定的 に上昇率が変わっている部分がありそれが推論 4 回目の 時間である，そこでアルコールのグレードが決定的に大 きくなっている. そのためこの部分で判別を終了したも のもあり, 平均推論回数は 5.5 回となっている. 低濃度 ではガスのパターンが水素, 都市ガスと類似しており推 論は 8 回まで行われた。

水素; 水素ガスはアルコール, 都市ガスと形状は良く 似ているが，その感度の上昇の具合いが若干異なってい る.その上昇の具合いを捕らえて判別していると思われ る.ただ, 決定的な特徵にそしく推論は最後まで行われ ている. 水素の誤判別ガスはアルコールと都市ガスで, この原因はアルコールのパターンのうち低濃度のもの は, 水素ガスのパターンを少し強調したような形になっ ており，水素のパターンをアルコールのパターンに誤判 別したと考えられる.

都市ガス ; 都市ガスについては, 都市ガスの 40\%の成 分が水素ガスであり,もともとのパターンが酷似してい るのでもともと判別は難しかった. 判別できたのはほか の成分の影響がでたのではないかと推測している，この 結果を以前の方法 ${ }^{1)}$ と比較して, 水素ガスの判別率は同 程度 (66.6\%)であり, 都市ガスに関しては, 50.0\%から $79.1 \%$ 向上しており改良されている.さらに判別率を 向上させるためには異なった特性をもつセンサを組み合 せて判別することが必要と思われる。
Fig. 4 の推論のグレードの変化をみたとき, 目的とす るガス以外にグレードが大きくでたガス種が存在するこ とがわかる。これは単純にガスのパターンが似ているた めである。これをガスパターンのグループとして考え, 相互誤判別ガスを考慮すればプロパン・ブタンを一つの グループ, 水素・都市ガス・アルコールを一つのグルー プ,メタンのグループに分けられる.グループの識別後, グループ別にフィードバックを行い，ヒータ温度を微妙 に制御することで，類似パターンのガス判別率を向上さ せることは可能ではないかと思われるが, 今後の課題で ある。

そのほか誤判別の要因として，時間区分の与え方によ るものも大きいが，任意に感覚で選べるという利点を考 えると,この結果はまずまずではないかといえる.ただ， 変化のないところを選んでしまっては判別の要素にはな らない. 特徵的な範囲を自動的に範囲を選択するように すれば，人間の手を加える必要はなく, 判別率が安定, 向上するのではないかと考えられる。

選択するガスパターンであるが，類似ガスのパターン に関してはセンサの特性に依存しており別のセンサを利 用して，その類似ガスに対応できるようにすることで判 別率は向上するだろうと考えている.

今回の 6 種類のガスの判別では, 濃度を考慮せずにガ ス種の判別のみを目的として行った，濃度についてはガ ス種の決定後センサの濃度に対する感度曲線により求め ることが出来ると考えている.

今回行った実験ではセンサのデー夕範囲がある範囲内 であれば十分有効であるが, 繰り返し実験を行っていく うえで, センサ出力に変動があり, データのばらつきが 許容範囲を越えた場合では判別失敗が多かった。

\section{5. ま と め}

本論文ではファジィ推論を用いたガス判別法の提案を 行った. ヒー夕電圧を制御してガスの特徵を抽出する. そして各ガスの応答パターンを時間的に分割し, 分割し た時間でのパターンの傾きをファジィ化する．そして行 列を作成し，任意の入力と比較しながら推論を行う方法 である.この方法を用いて実験を行った結果, 6 種類のガ スパターンについて特徵的な時間を選び出し, ファジィ 行列の作成を行い，それによりガス判別を行うことがで きた。

6 種類のガスについて, 水素 $66.6 \%$, プロパン $79.1 \%$, ブタン $100 \%$ ，メタン $100 \%$, 都市ガス $79.1 \%$, アルコー ル $91.6 \%$ という良い判別率を得ることが出来た。

今回のシステムは単純で, ガスの特徴を抽出するため の計算量も少ない. また逐次的に判別を行っているため, 
パターンデータ全てを必要とせず，推論途中の早い時間 でガス判別が可能な場合, そこで処理を終了する。また 判別困難な場合はさらに同様の処理を行い推論を繰り返 すという単純な構造である。

またガスの特性はヒータの温度特性に依存することが わかっている，センサを複合化する場合も同様な処理を 全てのセンサに行えば良いと考えられる。

\section{6. おわりに}

今回の結果から，七ンサ 1 個で判別可能なガス種が多 ければ複数化した場合，単純に考えて $N$ 個のセンサな ら，1個の場合の $N$ 倍のガスを判別することぶ可能では ないかと考兄られる.1個でできるだけ判別法を単純化 しておけばセンサを複数化しても全体のシステムを簡略 化できる利点がある．またヒー夕の温度によりガスの特 徵を抽出することができるので, 今後は現在の判別シス テムを, 濃度推定, 成分分析なども扱えるように発展さ せる必要があると考えている。

\section{参 考 文 献}

1）竹歳, 小林, 小西, 笹倉: Fuzzy 理論を用いたガス判別, 計測自動制御学会論文集, 27-5, 503/508 (1991)

2) 石㴊, 田中, 福岡: ファジィデータの判別分析とガスセン サシステムへの応用, 日本ファジィ学会誌，1.1-1, 117/ 131 (1989)

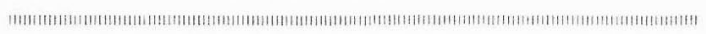

\section{[著 者 紹 介]}

\section{青 木 徹}

1991 年, 鳥取大学工学部電子工学科卒 業. 同年同大学大学院修士課程入学. ガス センサシステムに関する研究に従事。

小西亮介（正会員）

1968 年, 神戸大学工学部計測工学科卒 業. 70 年同大学大学院修十課程修了. 同年 鳥取大学電子工学科助手, 77 年同助教授 なり，現在に至る。薄膜・表面物理・マイ クロコンピュータの計測への応用に関する 研究に従事 (工学博士).

\section{木 村 壽 成}

1992 年, 鳥取大学工学部電子工学科卒 業. 同年富士通九州デジタルテタノロジー に入社.

\section{末 次大 祐}

1992 年, 鳥取大学工学部電子工学科卒 業. 同年三菱電機エンジニアリングに入社.
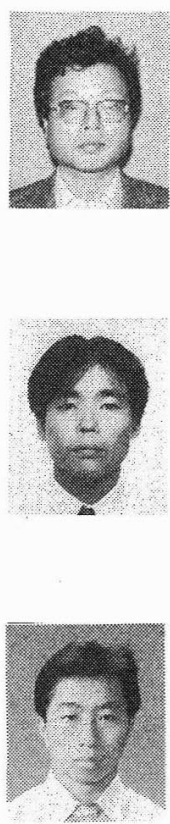